„Bohemistyka” 2020, nr 2, ISSN 1642-9893

Simona KATHEBOVÁ

DOI: $10.14746 /$ bo.2020.2.11

Masarykova univerzita

\title{
Syntax mluvené češtiny ${ }^{1}$
}

Publikace Syntax mluvené češtiny ${ }^{2}$ je výsledkem kolektivního úsilí, na němž se podílel trrináctičlenný tým sestávající ze starší i mladší generace lingvistů působících na Ústavu pro jazyk český (ÚJČ) AV ČR, Ústavu Českého národního korpusu (ÚČNK), Univerzitě Karlově a Univerzitě Hradec Králové. Výsledek vyšel v rámci stejnojmenného projektu podpořeného Grantovou agenturou ČR. V návaznosti na předchozí výzkumy autoři vychází z přesvědčení o existenci obecných univerzálních syntaktických charakteristik mluveného jazyka, jejichž komplexnější a podrobný popis dosud chybí. Ačkoli v rozsahu jedné knihy není možné obsáhnout systematickou a ucelenou deskripci syntaktických jevů mluvené češtiny, práce nabízí hloubkovou

${ }^{1}$ Tento př́spěvek vznikl na Masarykově univerzitě v rámci projektu Čeština v jednotě synchronie a diachronie - 2019 číslo 1061/2018 podpořeného z prostředků účelové podpory na specifický vysokoškolský výzkum, kterou poskytlo MŠMT v roce 2019.

${ }^{2}$ Jana Hoffmannová, Jiří Homoláć a Kamila Mrázková (eds). Syntax mluvené češtiny. Praha: Academia, 2019, 396 s. ISBN 978-80-200-2961-4. 
analýzu některých závažných témat, nahlížených nejen z perspektivy dosavadních výzkumů mluvené češtiny (zahrnující zvláště přístupy gramatické, stylistické a fonetické) (uvádějí se zejména M. Grepl 1962; K. Hausenblas 1962; M. Šipková 1993; O. Müllerová 1994, I. Bogoczová et al. 2000, S. Čmerjková - J. Hoffmannová (eds.) 2011 ad.), ale i prizmatem moderních zahraničních lingvistických disciplín, z nichž většina se v české lingvistice uplatňuje relativně nedávno (především se jedná o konverzační analýzu, interakční lingvistiku, analýzu diskurzu, konstrukční gramatiku a korpusovou lingvistiku). V pozadí tohoto interdisciplinárního teoreticko-metodologického pojetí stojí 1) snaha vymanit se z dosavadního restriktivního hodnocení mluvenostních (skladebních) rysů v kategorích odchylky, anomálie a defektu, k němuž docházelo $\mathrm{v}$ důsledku poměřování mluvených projevů normami psaného textu, a 2) pokus naleznout terminologický konsensus mezi jednotlivými teoreticko-metodologickými př́stupy a zvážit jejich ústrojnost a adekvátnost při analyzování jednotlivých jevů za účelem postihnutí jejich funkční podstaty v kontinuu řeči, respektive v projekčních a interakčních mechanismech mluvených dialogů. Neopominutelnou součástí zvolené metodologie je systematické sledování syntaktických jevů ve spojení se zvukovými (zejména prozodickými) prostředky za využití moderních analyzátorú řeči. Cenným doplňkem publikace je soubor vybraných audionahrávek, na něž se v jednotlivých kapitolách průběžně odkazuje, dostupný na webových stránkách ÚJČ AV ČR

Materiálovou základnu autorům poskytla zejména data mluvených korpusů ČNK, př́ípadně také nahrávky vlastní, přičemž v popředí zájmu byly především korpusy neformálních, nepřipravených dialogů (např. ORAL2013 a nejnovější ORTOFON), zároveň byl také využíván korpus DIALOG, sestávající z videonahrávek a přepisů televizních dialogických pořadů, které lze považovat projevy za veřejné, nicméně nanejvýš polopřipravené. Pro dané účely by přirozeně nebylo vhodné brát v potaz rétorické, monologické, předem (písemně) připravené komunikáty.

Publikace obsahuje devět kapitol, na nichž se (mj. pro metodologickou náročnost a tematické rozpětí) jen výjimečně podílel pouze jeden autor. Jejich tematiku zde nyn výběrově představíme. Jak bylo zmíněno výše, významným východiskem většiny kapitol je interakční lingvistika a konverzační analýza, jelikož akcentují procesuálnost a interakční povahu mluvených dialogů. K úspěšnému vedení dialogů a hladkému vystř́́dání komunikačních partnerů slouží verbální a neverbální prostředky, kterými mluvčí dávají najevo, co bude v rozvíjené replice či v průběhu rozhovoru následovat. Na tomto principu je založena tzv. projektivita, ústřední pojem moderního konceptu on-line syntaxe P. Auera (2009), který je aplikován v kapitole M. Havlíka a E. Zaepernickové Temporalita a interakce v rozhovorech: syntaktické a prozodické aspekty projektivity $a$, dodatku““. Prostor věnují autoři mj. konkrétní ukázce analýzy projektivity, dále poněkud novému fenoménu - uptalku, jímž je označováno výrazné stoupnut hlasu na konci výpovědi (která však není koncem repliky) užité za účelem zabráněn výměně komunikačních rolí. Na př́ikladu dodatků, výrazů syntakticky závislých na předchozí výpovědi, autoři dokládají, že aktuální větné členění nemusí být jediným pořádajícím principem českého slovosledu, jelikož dodatky v rematické pozici mohou být pouze upřesněním (uloženým na konec výpovědi v důsledku časové tísně), nikoli zásadní novou informací.

Projektivita je předmětem úvah také K. Mrázkové a J. Homoláče, kteří ve své stati Verbálně signalizované sebeopravy nahrazenim ve veřejných mluvených textech vysvětlují, že nahrazení je projektováno původní výpovědí a vlastní oprava projektuje další její pokračování, což umožňuje mluvčím opravit pouze část fráze, aniž by ji museli zopakovat celou. Dokazují tímto, že sebeopravy nahrazením nejsou nahodilé řešení lokálního problému, ale plnohodnotný syntaktický prostředek mluveného jazyka.

S procesuálností mluvené řeči jsou spojeny tzv. překryvy replik, jimž se ve stejnojmenné kapitole věnují Z. Komrsková, P. Poukarová a M. Havlík. Jejich cílem je představit tento jev jako integrální součást spontánní komunikace, přičemž poukazují na existenci překryvů kooperativních i kompetitivních (které nelze omezit na pouhé „skákání do řeči“).

Významnost interakčních aspektů potvrzuje frekventovaný výskyt nepřízvučných výrazů sem, se, si, ti, by ad. v místech následujících po vystř́idání mluvčích či po kontinuátoru, kterým recipient povzbuzuje mluvčího k pokračování v řeči. Korelací jednoslabičných začátků s prozodickými prostředky a kvantifikací jednotlivých výrazů na základě korpusových dat se zabývá v kapitole Redukované (jednoslabičné) nepř́żvučné začátky výpovědi a dialogických replik autorská dvojice J. Hoffmannová a O. Richterová.

Metody korpusové lingvistiky byly využity též v př́íspěvku následujícím: Reprodukce řeči/myšlení v mluvených projevech, v níž se autorky J. Hoffmannová, Z. Komrsková, P. Poukarová a E. Zaepernicková věnují mj. častosti výskytu verbálních signalizátorů reprodukce řeči, zejména verb dicendi řikat/řict a částice prý (včetně jejich regionálních variant). Pozornost je upírána též na signalizátory prozodické a paralingvální, které byly podrobeny kvalitativní analýze.

J. Zeman upozorn̆uje na Některé specifické syntaktické konstrukce př́značné pro mluvenou češtinu, které bývají tradičními popisy hodnoceny jako strukturně a logicky defektní (zvláště zeugma a anakolut), nicméně adekvátnímu přijetí myšlenkového obsahu v mluvené interakci však nebrání. Nadto v př́ípadě zeugmat lze podle autora sledovat řadu pravidelných struktur.

V kapitole Otázky v mluvené češtině provedl J. Zeman s oporou o východiska kognitivní lingvistiky interpretaci pravých (kognitivních) otázek. V témže textu se J. Hoffmannová a L. Jílková zabývají velmi specifickou zvukovou realizací nepra-

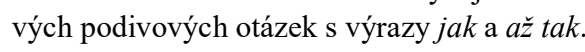


M. Fried přispěla tematicky i metodologicky náročnou statí Interakčni dativ $v$ běžně mluvené češtině, v níž propojuje př́istupy konstrukční gramatiky a konverzační analýzy, aby popis na první pohled čistě gramatického jevu rozšíríla o rovinu komunikační a sociopragmatickou. Ve funkci interakčního dativu vystupují atonická zájmena v 1. a 2. osobě singuláru i plurálu, která autorka podrobuje kvantitativní i kvalitativní analýze (věnuje se konkrétním funkcím: mj. odkazování k adresátovi, vyjádření neobvyklé míry, údivu).

Závěrečná kapitola autorek A. Čermákové, L. Jílkové, Z. Komrskové, M. Kopřivové a P. Poukarové s názvem Diskurzni markery představuje značně diferencovaný soubor jazykových prostředků stojících na pomezí lexika a syntaxe, jehož označení vychází z klasických prací diskurzních analytiků (mj. D. Schiffrin 1987). Jedná se o otevřenou skupinu výrazů (zahrnující prvky kontaktové, vycpávkové až po hezitační zvuky, např. hele, hej, no, jakoby, vlastně, hm, eee), problematických z hlediska slovnědruhového zařazení, které svojí funkcí (narušováním, nebo naopak udržováním koherence textu) spadají rovněž do oblasti zájmu textové lingvistiky (podobně jako např. dodatky, opravy, otázky, jimž byly věnovány předešlé části knihy). Cílem autorek je především vytvořit funkční klasifikaci vybraných diskurzních markerů a zohlednit též jejich zvukové charakteristiky.

Monografie Syntax mluvené češtiny představuje tematicky i metodologicky náročné dílo, jehož předností je moderní interdisciplinární př́stup, který však současně důsledně reflektuje výsledky dosavadních domácích výzkumů, čímž plní do jisté míry také funkci přehledové práce. Neopominutelným kladem knihy je čtenářsky přívětivá forma, zejména logické a takřka jednotné uspořádání výkladu jednotlivých kapitol, kterého se i přes značné tematické rozpětí podařilo editorům (J. Hoffmannové, J. Homoláčovi a K. Mrázkové) dosáhnout. Publikaci lze bezpochyby považovat za významný inspirační zdroj pro další bádání. Autoři v rozsahu jedné knihy samozřejmě nemohou (a ani nechtějí) podat definitivní řešení a předvést tak přehled typických rysů mluvených projevů, a to ani na pozadí projevů psaných, tedy jednoznačně říci, čím se liší. Vysoká náročnost úkolu spočívá ve skutečnosti, že unikátní povah jednotlivých (většinou spontánních) promluv takřka vyrůstá z konkrétních komunikačních situací, které jsou rozmanité jako život sám. 